As provas de exames de admissão são as seguintes:

- Prova de Aptidão Cultural;

- Prova específica de Matemática (duas, preferindo-se, para efeitos de classificação, aquela em que o candidato obtenha classificação mais elevada).

Por sua vez, para a admissão ao $1 .^{\circ}$ Ano, é exigido aos candidatos que possuam o $12 .^{\circ}$ ano de escolaridade em cursos em que a Matemática seja disciplina de base e que tenham realizado a prova de aferição.

As provas de exame de admissão ao $1 .^{\circ}$ ano são, também, a de Aptidão Cultural e a específica de Matemática (duas, observando-se o critério de preferência pela melhor das notas obtidas).

Quando se efectuam reestruturações curriculares, podem adoptar-se diversos critérios, nomeadamente aplicar a reestruturação apenas aos alunos que se vão matricular no $1 .^{\circ}$ Ano, ou, em alternativa, prever a possibilidade de transição dos alunos dos outros anos (designadamente dos que, no ano lectivo em que a reestruturação se efectuou, se encontram a frequentar o $1 .^{\circ} \mathrm{e} \mathrm{o} 2 .^{\circ}$ anos do curso).

Na presente reestruturação, optou-se pela segunda hipótese, embora de uma forma limitada. O que significa que, sem prejuízo de os actuais alunos do $1 .^{\circ} \mathrm{e}$ do $2 .^{\circ}$ anos permanecerem até ao fim do curso no plano de estudos que iniciaram, lhes é facultada a possibilidade de transitarem para o novo plano de estudos. Neste sentido, os alunos do $1 .^{\circ}$ e $2 .^{\circ}$ anos puderam optar, já no ano lectivo de 1994/95, pelo novo currículo ou pelo anterior.

A implementação da reestruturação curricular tem exigido um notável esforço do I.U.D.P.S., atendendo à entrada em funcionamento do novo plano de estudos no $1 .^{\circ}$ ano da licenciatura, bem como ao funcionamento de um regime transitório para os alunos do $2 .^{\circ}$ e $3 .^{\circ}$ anos que optaram pelo currículo reestruturado.

\title{
2. CURSO DE PÓS-GRADUAÇÃO EM GESTÃO DE EMPRESAS
}

O Instituto Universitário de Desenvolvimento e Promoção Social e a Faculdade de Ciências Económicas e Empresariais promoveram o lançamento, no decorrente ano lectivo, do Curso de Pós-graduação em Gestão de Empresas.

Tendo como objectivos primaciais permitir a abertura de novas perspectivas e adquirir os instrumentos indispensáveis ao desenvolvimento de soluções concretas para problemas reais da gestão, o Curso de Pós-graduação em Gestão de 192 Empresas iniciou-se, consoante o previsto, em Outubro do decorrente ano lectivo, 
distribuindo-se por quatro trimestres, o último dos quais terminará em Dezembro de 1995.

Sob a competente direcção do Prof. Doutor Fernando do Nascimento (da FCEE/UCP), o Curso de Pós-graduação é frequentado por 29 alunos, que estão inscritos nos 12 módulos que integram o respectivo plano curricular, e por três licenciados com o estatuto de alunos externos.

\section{HOMENAGEM A MONSENHOR CELSO TAVARES DA SILVA}

Na sequência de iniciativa da Reitoria da Universidade Católica Portuguesa e da Diocesse de Viseu, foi prestada homenagem, no dia 05 de Novembro de 1994, a Monsenhor Celso Tavares da Silva, que foi dedicado e competente Secretário do Centro Regional de Viseu da UCP e Membro do Conselho de Direç̧ão do I.U.D.P.S., de 1989 a 1994.

A referida homenagem, a que se associou intensamente o I.U.D.P.S., comportou diveros actos, de que se destacam a Missa celebrada por S. Ex. ${ }^{a}$ Rev $^{\text {ma }}$ o Senhor Bispo de Viseu, no Seminário Maior de Viseu, e a sessão solene, realizada no Auditório Engenheiro Engrácia Carrilho, à qual presidiu o Magnífico Reitor da Universidade Católica Portuguesa.

Como tributo de homenagem a Monsenhor Celso, o Conselho de Direç̧ão e os docentes do I.U.D.P.S. ofereceram-lhe uma salva de prata, tendo também estado presentes, na sessão solene, numerosos professores e estudantes do Instituto. No decurso daquela, usaram da palavra: os Directores do I.U.D.P.S. e da Faculdade de Letras, o Presidente do Centro Regional das Beiras, S. Ex. ${ }^{\mathrm{a}}$ Rev. ${ }^{\mathrm{ma}}$ o Senhor Bispo de Viseu, o Magnífico Reitor da Universidade Católica Portuguesa e o homenageado.

Como coroamento da referida homenagem, o I.U.D.P.S. dedicará o $4 .^{\circ}$ volume de GESTÃO E DESENVOLVIMENTO a uma miscelânea de estudos em honra de Monsenhor Celso Tavares da Silva.

\section{CERIMÓNIA DE BENÇÃO E ENTREGA DE DIPLOMAS DA LICENCIA- TURA EM GESTÃO E DESENVOLVIMENTO SOCIAL}

Dando continuidade a uma tradição, iniciada em Janeiro de 1993, no que concerne à licenciatura em Gestão e Desenvolvimento Social, realizou-se, no dia 14 de Janeiro do corrente ano, a cerimónia de bênção e entrega de diplomas aos 